\title{
Questioning the Notion of Superman in Dostoevsky's Crime and Punishment
}

Neupane Khagendra, $\mathrm{PhD}$

\begin{abstract}
In the novel, "Crime and Punishment", the researcher analyzes how Raskalnikov, the protagonist, suffers from over ambition.Raskalnikov deliberately assassinates the old pawnbroker, Alyona Ivanovna, motivated by the desire of becoming asuperman. He violates law of the land and moral codes to prove his extraordinary strength at the pretext of transforming the society. He tries to substantiate his criminal act in order to protect the superman theory. However, his guilty conscience does not allow him to do so. Equally, his wife, Sonia, plays a key role to overcome his fragile logic of the theory. Finally, his dream of becoming the superman gets shattered.
\end{abstract}

Key Words: Crime, punishment, sin, superman and confession.

Set in Saint Petersburg, Russia, Fyodor Dostoevsky's Crime and Punishment highlights the role of Raskalnikov, the central character. The protagonist murders a former pawnbroker, Alyona Ivanovna and his sister Lizaveta with a hope offreeing the society from corruption. He commits crime being motivated by the philosophy of the superman which validates shedding blood to transform society. The idea of superman criminalizes his mind: "Criminal behavior is learned and it is learned in interaction with others who have already incorporated criminal values and illegitimate opportunities including conditions favorable to the learning of such role” (Sunderland 250). Raskolnikov justifies his criminal act:

I was ambitious to become a Napoleon; that was why I committed the murder. The fact is that one day I asked myself the following question supposing Napoleon to have been in my place. Supposing that to advance his career had neither Toulon nor Egypt nor the crossing of Mont Blanc, but in lieu of all these brilliant exploits was on the point of committing a murder with a view to secure his future would he have recoiled at act of killing an old woman and robbing her of three thousand Roubles? Would he have agreed that such a deed much preferring in prestige than a criminal one? I finally came to the conclusion that he not only would have but that he would not have understood the possibility of such a thing. Every other expedient being out of his reach he would not have flinched, he would have done so without the smallest scruple. (329-330)

Raskolnikov classifies all men into two categories: ordinary and extraordinary. He believes that the ordinary man is inferior and has no right to break the law. The extraordinary man, on the other hand, "has the right . . . that is not an official right, but an 
inner right to decide in his own conscience to overstep . . . certain obstacles, and only in case it is essential for the practical fulfillment of his idea, sometimes, perhaps, of benefit to the whole of humanity" (254). Raskalnikov's extraordinary theory of man is a combination of the logic of Nietzsche and Hegel. The Hegelian superman acts for a noble cause. If the results are noble, the means can be justified. The Hegelian superman stands above the ordinary man, and works for humanity. Raskalnikov tries to follow the philosophy adopted by the Hegelian superman and considers that his objective to murder the former pawnbroker is very noble. The protagonist removes the evil force of the society as prescribed by Hegel. Hegel asserts that any harmful segment of society should be removed and assassinated. By assassinating the old pawnbroker, the protagonist removed something harmful from society:

A hundred thousand good deeds could be done and helped, on that old woman's money ... hundreds, thousands perhaps, might be set on the right path; dozens of families saved from destruction, from ruin, from vice, from the lock hospitals and all with the money. Kill her, take her money and with the help of it devote oneself to the service of humanity and the good of all ... one death, and a hundred lives in exchange-it's simply arithmetic! (63)

Raskolnikov holds that the two classes (ordinary and extraordinary) have equal rights to exist in society.In the absence of the extra ordinary man, the human race would be discontinued. Without the ordinary men, the efforts and ideas of the extra ordinary man would be null and void. Raskolnikov, being obsessed with his theory of the superman, constantly tries to prove that he possesses the key attributes of the great man. He dreams of becoming an important figure like Napoleon. He believes that some people are superior to the ordinary human and above the moral law. He experiments with the concept of superman by murdering an old woman, a greedy money lender:

I needed to experience something different, something else was pushing me along: what I need to find out then, and find out as soon as possible, was whether I was a louse like every body else or man, whether I was capable of stepping over the barriers or not. Dare I stoop and take power or not? Was I a trembling creature or Had I the right? (402)

Raskolnikov tries to gain popularity in the society by raising social fund on the one hand and on the other, by freeing the society from an evil force after killing the horrible person. Comparing himself to Alexander the Great and Napoleon, he clarifies why they had to kill innocent people to achieve their goals: "I wanted to be Napoleon and that is why I killed her" (397).I wanted to have the courage, and I killed .... I only wanted to dare, Sonya, that was the only reason. .. "(401).

Dostoevsky presents the theory of the superman through his protagonist, Raskalnikov. Dostoevsky interprets events and his attempt to reconcile his ideas with his 
actions. He derides the notion of an extraordinary man, and offers it as a barely possible possibility: "Generally speaking, there are extremely few people, strangely few, born, who have a new idea, or are even capable of saying anything at all new... One genius may emerge among millions, and a really great genius, perhaps, as the crowning point of many thousands of millions of men" (252). Dostoevsky unfolds that the young intellectual gets influenced by various theories, and uses them before having the opportunity to analyze them. For the protagonist, murder is for the benefit of humanity and an extraordinary man must transcend mundane world.

Raskolnikov believes that he holds the qualities of a superman. As Superman has a special privilege, he dominates others, and demands no justification for his action, even the crime: "He [Raskolnikov] pulled the axe quite out, swung it up with both hands, hardly conscious of what he was doing, and almost mechanically, without putting any force behind it, let the butt-end fall on her head (73). Raskolnikov further justifies why he murdered Alyona Ivanovna and her sister Lizaveta: "Ordinary people must live in submission and do not have the right to break laws, because, you see, they are ordinary. And extra ordinary people have the right to commit any crime and to break all kinds of laws simply because they are extra ordinary” (248-50).

Raskalnikov believes that he is above the laws that govern ordinary people. He embraces the theory of the superman: a man superior to other humans, and therefore above the moral and legal rules which control the rest of society by legal or illegal action at his will. The murder of Alyona Ivanovna is also the result of his desire to test his so-called extra-ordinary theory. Therefore, he violates the existing rules and laws of the country. He resembles a nihilist, and asserts that it was Dostoevsky who laid the foundations on which Nietzsche built his theory of nihilism: "Dostoevsky was the first upon nihilism ... building upon the foundation ... Nietzsche conceived nihilism metaphysically and in its worldwide and historical relationship” (Masaryk 73).

Raskolnikov murders the pawnbroker believing that he is above the law and attempts to establish his superior role in society. Using the superman theory, he tries to defend himself so that he can save his face in the eyes of laws and rules.This murder consolidates his attempt to prove himself as a superman by shaking off his indolence. Raskolnikov thinks that he too can seize power like Napoleon and prove himself as a divine superman. Contrary to this vision of an act of liberation, he suffers from sense of guilt. In his dream, an invisible force laughs so strangely at his helplessness. He stands over the woman by brandishing his phallic ax.But she and the invisible masses just laugh at his face. He gets humiliated and faces the sign of male weakness. He finds weak and caged by his paralyzing paranoia: 
Perhaps the old woman was a mistake, but she's not the point! The old woman was only a symptom of my illness. . . I wanted to overstep all restriction as quickly as possible . . . I killed not a human being but put a principle! Yes, I killed a principle, but as for surmounting the barriers, I didn't do that; I remained on the side. . . The only thing I knew how to do was kill! And I couldnot do that properly either, it seems . . .. (263-4)

Raskalnikov never gets socialized because of his arrogance and evil act: "Raskolnikov was not used to the crowd and had avoided all social contacts" (10). In his conversation with Petrovich, Petrovitch, surprisingly, tells him about his isolation: , "what an odd character you are! You live so isolated that you don't know even things like this that directly concern you" (248).Raskolnikov believes that the extraordinary man is above suffering because he can break and create the laws. He thinks that he was extraordinary, sohe could commit any crime and remain indifferent towards it. However, he fails to overcome his guilt and his emotion overpowers him. It indicates that he cannot break the moral laws that govern normal men.

Raskolnikov neither assassinates the pawnbroker to earn his fortune nor uses the money for his amenity. Instead, he hides it under a rock for fear of being taken for his crime. An extraordinary man would not have been so meek rather he should have been bold and continued his goal. Instead, insecurity and guilt engulf him and he finds it difficult to accomplish even the simplest tasks: "What is it all about? How could it possibly be happening? He repeated to himself, seriously wondering if he had gone mad [...] oh God!' He thought of fastening his door, but could not raise his arm . . .. Fear crept like ice round his heart, tortures his nerves, numbed his spirit” (110).After Raskolnikov's assassination act,he reveals his guilt by returning to the apartment in which he killed the pawnbroker and his sister and by hiding the objects he obtained at the crime scene: “'No, I 'm not strong ...' he thought. His legs were shaking. 'With fear,' he muttered to himself. He felt dizzy and the fever had given him a headache. 'This is a trap. They want to entice me into a trap and then spring it ... I might get caught in some stupid lie'” (89)

Because of Raskalnikov's lack ofself-confidence, he initially hesitates to kill the pawnbroker. He fears that he is not sure the circumstances are right. In reality, he doubts his own ability to kill the pawnbroker and escape the punishment: "Why did I go out now?" Can I really be able to? Am I really serious? No, of course, I am not serious. So am I just having fun with fantasies, children's games? Yes, I may only be playing a game "(2). Raskalnikov's sense of guilt and insecurity shows that he is a kindhearted and emotional being which we do not find in superman. Ultimately, he surrenders to the authorities and is sentenced to prison in Siberia. 
Raskolnikov, like an ordinary man, falls in love with Sonia. He dreams of becoming a superman but in vain. Ultimately, he surrenders to divinity and holds that God will forgive him for his material sins. He internalizes death in a metaphorical sense believing that God will take him to heaven. His belief in God, his passage to heaven and surrender to authority reveal the fact that he is not a superman as defined by Hegel. Thus Zarathustra spoke, "I conjure you, my brethren, remain the true to the earth, and believe not those who speak unto you of super-earthly hopes! Prisoners are they, whether they know it or not” (8).

Raskolnikov realizes his weakness and understands his strength: he is "not Napoleon" (401), even more; he finally accepts to Dunya that he "didn't even manage to accomplish the first step" because he is nothing more than a "miserable wretch!" (498). He gradually loses his confidence over his theory. At the end of the novel, he completely gives up his own theory. He admits the murders to Sonia who represents "the pre-rational faith of a religious vision of the previous world" (Cassedy 70). Raskolnikov admits: "It was I killed the old pawnbroker woman and her sister Lizaveta with an axe and robbed them.” (511).

Sonia encourages Raskolnikov to go to the police and confess his crime to God and ask for forgiveness: "Go to the crossroads, greet the people, kiss the earth, because you have sinned against you too, and say aloud to the whole world. I am a murderer. He knelt in the middle of the square, bowed down to the earth and kissed this dirty earth with blessing and rapture"(485). It was only after Raskolnikov's confession to Sonia that he had murdered him. Richard Gill declares: "It is only when Raskolnikov is riddled with fear and madness that he accepts Sonia's teachings, his willpower and his lesson in regeneration through humility" (150 Raskolnikov leads a tormented struggle between vice and virtue in his dualistic heart: "[. impulses which push his dualist to kill then to repent "(Summons 27).

Sonia succeeds in bringing Raskalnikov back to reality by relieving him from his guilt. She achieves this by fusing the moral and spiritual entities that Raskolnikov ignored initially. Raskalnikov realizes that his act of murdering the two women is a crime, and he must repent for it and ask for the atonement: “Oh my God! . . Oh, I'm miserable! ... Why, why didn't I know you before? Why haven't you come before? (395). Finally, Raskalnikov submits to the law of the land: ". . . already felt in his heart that there was something deeply wrong in himself and in his beliefs. He did not understand that this feeling could have been the announcement of coming crisis in his life, of his coming resurrection, of a new vision of life "(521). Raskalnikov's theory finally fails to attain his desired goal. He begins a new life with Sonia. The conjugal life regenerates him spiritually, and establishes the moralist author: "Dostoevsky can point the moral in the imperishable stuff of humanity; he can show the very pulses of heart which drives the murderer to the stool of repentance” (Murry 33). 
Dostoevsky explores human psychology through Raskalnikov, the main character, who dreams to be an extraordinary man by violating social norms and laws. He envisions to be a superman by murdering a pawnbroker and a lady, a money lender. He justifies the murder of Alyona for utilitarian reasons. He exhibits his nihilist attitude, ignoring human emotions and social conventions. However, he becomes unable to control his guilty conscience that makes him realize that he is an ordinary man. He abandons nihilism by discovering love in the form of Sonia.Sonia's love adds serenity that helps him to admit his crime. Ultimately, he returns to reality by accepting the failure of the superman theory.

\section{Works Cited}

Cassedy, Steven. Dostoevsky Religion. Stanford, CA: Stanford UP, 2005. Print.

Dostoevsky, Fyodor Mikhailovich. Crime and Punishment. Trans. Jessie Coulson, Oxford University Press, New York, 1980. Print.

Gill, Richard. "The Bridges of St. Petersburg: A Motif in Crime and Punishment." Dostoevsky Studies 3 (1982): 145-55. Print.

Masaryk, Thomas Garrigue. The Spirit of Russia; Studies in History, Literature and

Philosophy. Trans.Eden, Paul and Slavik, Second ed. London: George Allen and Unwin, 1955.

Murry, J. M. Fyodor Dostoevsky: A Critical Study. Boston: Fontana Press, 1924.

Summons, E J. Dostoevsky, The Making of a Novelist, New York and London: Columbia University Press, 1969. Print.

Sutherland, Edwin Hardin. The Professional Thief. Chicago: U of Chicago Press, 1937. Print. 